\title{
Host-plant specialisation and habitat restriction in an endangered insect, Lycaena dispar batavus (Lepidoptera: Lycaenidae) II. Larval survival on alternative host plants in the field
}

\author{
LYNN A. MARTIN ${ }^{1}$ and ANDREW S. PULLIN ${ }^{2 *}$ \\ ${ }^{1}$ Department of Life Sciences, Keele University, Staffs ST5 5BG, UK \\ ${ }^{2}$ School of Biosciences, The University of Birmingham, Edgbaston, Birmingham B15 2TT, UK
}

Key words. Butterfly ecology, larval survival, Rumex, fenland, competitive exclusion

\begin{abstract}
The Large Copper butterfly, Lycaena dispar batavus, is extinct in Britain and rapidly declining in Europe, due predominantly to loss of its wetland habitats. Northern populations have more specialised foodplant and habitat requirements than their more southerly counterparts and rely solely on Rumex hydrolapathum, the Great Water Dock, as their hostplants. Southern colonies use a greater range of Rumex. Previous work has shown that specialisation is not due to foodplant chemistry and in this paper we investigate the ability of different Rumex species to support the larval stages of $L$. $d$. batavus in a natural environment. Comparisons were also made between a captive colony at Woodwalton Fen, Cambridgeshire, UK and native larvae at De Weerribben, Netherlands. Field experiments using a captive colony revealed that other Rumex hosts can successfully support larvae throughout each of their larval stages in wet grassland and fenland habitats with no significant differences in survival rates compared with their natural hostplant $R$. hydrolapathum. An overwintering experiment using a native wild population of both butterfly and Rumex species in De Weerribben found $25 \%$ of larvae survived on the natural hostplant $R$. hydrolapathum and no survivors on alternative Rumex hosts. It is suggested that $R$. crispus and R. obtusifolius growing in their natural habitat may harbour significant competitors to $L$. $d$. batavus leading to its specialisation on $R$. hydrolapathum in fenland habitats.
\end{abstract}

\section{INTRODUCTION}

The subspecies of the large copper butterfly Lycaena dispar batavus is confined to the Netherlands and regarded as endangered (Oostermeijer, 1996). This subspecies, and related univoltine populations, that utilise a single larval foodplant Rumex hydrolapathum, have suffered the more severe decline due to wetland drainage and are currently of more conservation concern than the more geographically widespread bivoltine subspecies $L$. $d$. rutilus, which utilises a wider range of foodplants and habitats (Pullin et al., 1998).

In a previous study, Martin \& Pullin (2004) showed that the specialisation in host plant use and restriction in habitat use of L. d. batavus was not due to differences in nutritional acceptability of the plants. Female $L$. $d$. batavus lay eggs on a range of Rumex species in caged conditions but in the field, females lay eggs solely on $R$. hydrolapathum. Since this does not appear to be a nutritional specialisation, an alternative explanation is that each plant species may differ in its ability to provide suitable protection for larvae against the hostilities of their environment at one or more of their life stages. For example, L. d. batavus larvae are known to use the curled edges of dry senescent $R$. hydrolapathum leaves for their winter hibernacula and other Rumex species may (or may not) offer a similar overwintering location. Therefore, the ability of these alternative host plants to successfully support all three life stages to allow progression into the subsequent stages of development is crucial.
Survival of native larvae on $R$. hydrolapathum in the Weerribben has been found to differ between habitats, depending on the type of management experienced. Overall survival was higher on plants which had been cut in the previous year, and were regrowing, and were situated along watersides. Intermediate survival was found on fen edges and uncut watersides and the highest mortality occurred in fen meadows (Pullin, 1997). It could therefore be that differential survival among potential hostplant species is even greater, leading to specialisation.

The success of an insect on its host-plant within a particular habitat depends on its ability to overcome the hostilities of its environment. For example, food-plant quality (Slansky, 1993), secondary plant defences (Rhoades \& Cates, 1976) and natural enemies (Atsatt, 1981) and shelter from adverse conditions. Most of these factors will act simultaneously to influence host plant choice. Martin $\&$ Pullin (2004) have shown that there is little support for the former two in L. d. batavus; we assess the latter two here.

It has been suggested that the influence of natural enemies may play a larger part in host plant choice (Atsatt, 1981; Bernays \& Graham, 1988) to the extent that, in some cases, selection for enemy free space may be more important than food plant quality (Damman, 1987; Denno et al., 1990). Parasitoids and other aerial predatory invertebrates may use other search cues such as plant volatiles from damaged plant material (Thaler, 1999).

* Corresponding author. E-mail: a.s.pullin@bham.ac.uk 
The composition of a habitat may also be important and may influence predator numbers and/or predator diversity. For example, Smith \& Whittaker (1980a, b) found that habitat type influenced the success of the coleopteran Gastrophysa viridula, depending on whether they were present in a hayfield, monoculture, diverse or mature habitat and that the density of ground vegetation influenced the diversity and number of predatory fauna present.

Work carried out by Duffey (1968) and Webb \& Pullin (1996) on a captive colony of $L$. $d$. batavus held at Woodwalton Fen, using cages to exclude natural enemies, have found that larval mortality in all three life stages is high and that several factors may be responsible. Invertebrate predation, from spiders and other predatory insects, is largely responsible for mortality in the pre-diapause stage, whilst vertebrate predation, from birds and possibly small mammals (Duffey, 1968) are to blame during the post-diapause stage.

It is likely that each habitat will have a different invertebrate (and vertebrate) fauna that will offer different predatory pressures on immature insects. In this paper we report on investigations of larval survival of $L$. $d$. batavus on potential Rumex hosts in the field to assess if one plant species or one type of habitat offered preferential survival (or mortality) over the others. We investigate the ability of $L$. d. batavus larvae to survive on potential Rumex host plants $R$. crispus and $R$. obtusifolius compared to their natural host $R$. hydrolapathum during each stage of their life cycle, pre-diapause, diapause and post-diapause, as determined by the numbers starting and finishing each stage. We also compare larval survival on the three Rumex species growing in a fenland habitat with those growing in a drier grassland habitat and compare survival of the captive colony on the three Rumex species growing in fenland at Woodwalton Fen with native larvae in the De Weerribben, The Netherlands.

\section{METHODS}

Experiments were designed to assess whether larvae are able to survive under field conditions on three alternative Rumex species, $R$. hydrolapathum, the larval host plant of $L$. d. batavus, and two alternative species also used by $L$. $d$. rutilus, $R$. crispus and $R$. obtusifolius. Assessments of survival were divided into three key life cycle stages as follows;

Pre-diapause: the number of larvae completing this stage and entering diapause

Diapause: the number of larvae emerging from diapause

Post-diapause: the number of larvae completing this stage and pupating

Two experiments were conducted; one using a captive population at Woodwalton Fen National Nature Reserve, Cambridgeshire, UK and a second using a wild population at the Weerribben National Park, Overijssel, the Netherlands.

\section{Woodwalton Fen National Nature Reserve}

Experiments were run from September 1995 to May 1999. The butterflies used were from the captive population held on the reserve. Direct translocation from a wild Dutch population was not permitted at the time. Two sites were selected to reflect the natural growing habitats of the different Rumex species. Compartment 39 is a reed fen habitat, traditionally known as "The Copper Field" and is the natural habitat for $R$. hydrolapathum but where $R$. obtusifolius and $R$. crispus are not found. For the purposes of this study this is referred to as the fenland habitat. Compartments $84 \& 85$ in the south of the reserve were drier habitats where $R$. crispus and $R$. obtusifolius can occur naturally, and are referred to as the "grassland habitat". At this site the experimental plots were fenced off from grazing.

Although $R$. hydrolapathum is found growing naturally in the Fen along watersides, $R$. obtusifolius and $R$. crispus are not common inside the reserve and so, to ensure all plants had similar growing histories, potted plants grown under greenhouse conditions were used for all three species. At the study sites plants were dug into the ground in $3 \times 3$ Latin Squares (three of each plant per square) and three replicates of the Latin Squares for each site. The plants were situated $1 \mathrm{~m}$ apart to prevent larvae moving from one plant to another. As far as possible the surrounding vegetation was left undisturbed to ensure as near natural conditions. Between four and five larvae were assigned to each plant in each experiment, dependent on how many larvae were available for use. The larvae were reared in the laboratory under the appropriate natural seasonal temperature and light regimes before being transferred to the field. Fresh larvae were used for each separate experiment as survivors from previous experiments may have been parasitised or stressed in some way compared with greenhouse reared replacements.

Pre-diapause larvae: newly hatched first instar larvae were placed on experimental plants in late August to mid-September, the natural pre-diapause period for this butterfly, in each of the three years 1995-7. The larvae were placed on the surface of the leaves using a fine brush and allowed to move to their natural feeding positions. They were then left for four weeks and any survivors collected just before entering winter diapause. The plants were also collected and taken back to the laboratory for further examination for larvae missed in the initial collection.

Diapausing larvae: newly moulted second instar larvae and plants were put out into the field, in the same manner as described above, at the end of September, the beginning of natural larval diapause, in 1995-8 and left until the following spring. In late April surviving larvae that had successfully emerged from over-wintering and begun to feed were collected and counted. Plants were again examined in the laboratory for later emerging larvae. One year's data was omitted (1997/98) due to flooding of Woodwalton Fen before diapausing larvae had been recovered. A subsequent search found no surviving larvae.

Post-diapause larvae: a new batch of second/early third instar larvae and fresh plants were put out in late April, the beginning of the natural post-diapause period, in 1996-8 and left for four weeks. Survivors were then collected and counted. The surviving larvae from each experiment were reared separately to the adult stage in order to establish if any mortality occurred due to parasitism and if so, what species of parasitoids were likely to affect $L$. $d$. batavus larvae, and whether the rates of parasitism differed between the grassland and fenland habitats. Parasitism rates were analysed using the G-test (Fowler \& Cohen, 1990).

\section{The Weerribben National Park}

A comparative overwintering study of a wild population was undertaken in the Weerribben National Park in the north west province of Overijssel, the Netherlands in September 1997 and ran until mid-May 1998. An experimental site was located where all three Rumex species grow in close proximity. A narrow grass strip was chosen, approximately $7 \mathrm{~m}$ wide, with 
TABLE 1. Larval survival of Lycaena dispar batavus on 3 different Rumex species at Woodwalton Fen NNR 1995-1998, and De Weerribben in 1997. No. = number starting experiment. $\mathrm{S}=$ number surviving.

\begin{tabular}{|c|c|c|c|c|c|c|c|c|c|c|}
\hline \multirow[t]{2}{*}{ Site } & \multirow[t]{2}{*}{ Year } & \multicolumn{3}{|c|}{ R. hydrolapathum } & \multicolumn{3}{|c|}{ R. obtusifolius } & \multicolumn{3}{|c|}{ R. crispus } \\
\hline & & No. & $\mathrm{S}$ & $\%$ & No. & $\mathrm{S}$ & $\%$ & No. & $\mathrm{S}$ & $\%$ \\
\hline \multicolumn{11}{|c|}{ WOODWALTON FEN } \\
\hline \multicolumn{11}{|c|}{ Pre-Diapause } \\
\hline Grassland & 1995 & 45 & 2 & 4 & 45 & 2 & 4 & 45 & 15 & 33 \\
\hline Fenland & 1995 & 45 & 2 & 4 & 45 & 0 & 0 & 45 & 18 & 40 \\
\hline Grassland & 1996 & 36 & 6 & 17 & 36 & 10 & 28 & 36 & 10 & 28 \\
\hline Fenland & 1996 & 36 & 4 & 11 & 36 & 2 & 6 & 36 & 11 & 31 \\
\hline Grassland & 1997 & 45 & 13 & 29 & 45 & 7 & 16 & 45 & 5 & 11 \\
\hline Fenland & 1997 & 45 & 5 & 11 & 45 & 7 & 16 & 45 & 6 & 13 \\
\hline \multicolumn{11}{|l|}{ Diapause } \\
\hline Grassland & $1995 / 96$ & 36 & 0 & 0 & 36 & 2 & 6 & 36 & 0 & 0 \\
\hline Fenland & $1995 / 96$ & 36 & 2 & 6 & 36 & 2 & 6 & 36 & 3 & 8 \\
\hline Grassland & $1996 / 97$ & 36 & 1 & 3 & 36 & 3 & 8 & 36 & 0 & 0 \\
\hline Fenland & $1996 / 97$ & 36 & 9 & 25 & 36 & 5 & 14 & 36 & 2 & 6 \\
\hline Grassland & $1997 / 98$ & 45 & 0 & 0 & 45 & 0 & 0 & 45 & 0 & 0 \\
\hline Fenland & $1997 / 98$ & 45 & 0 & 0 & 45 & 0 & 0 & 45 & 0 & 0 \\
\hline Grassland & 1998/99 & 45 & 8 & 18 & 45 & 5 & 11 & 45 & 4 & 9 \\
\hline Fenland & 1998/99 & 45 & 3 & 7 & 45 & 4 & 9 & 45 & 3 & 7 \\
\hline \multicolumn{11}{|c|}{ Post-Diapause } \\
\hline Grassland & 1996 & 36 & 5 & 14 & 36 & 7 & 19 & 36 & 4 & 11 \\
\hline Fenland & 1996 & 36 & 3 & 8 & 36 & 6 & 17 & 36 & 2 & 6 \\
\hline Grassland & 1997 & 45 & 4 & 9 & 45 & 4 & 9 & 45 & 4 & 9 \\
\hline Fenland & 1997 & 45 & 6 & 13 & 45 & 2 & 4 & 45 & 3 & 7 \\
\hline
\end{tabular}

DE WEERRIBBEN

Diapause

$1997 / 98 \quad 20 \quad 5 \quad 25$

naturally occurring $R$. crispus and $R$. obtusifolius, situated adjacent to a water-body supporting $R$. hydrolapathum plants. This strip is mown twice a year (E. Jans, pers. com.) and Rumex grow along the edges. Five plants of each species were chosen and the plants left in situ. First instar larvae from the native population were translocated to the experimental plants in August. Four larvae per plant were used. One plant of each species was checked the following day for successful establishment of larvae on the plants. In each case three out of four larvae were visible and feeding windows observed. Plants were re-examined in mid September, no larvae were found actively feeding on any of the experimental plants. However, as no larvae were seen in other places in the park, it was assumed that any survivors had entered diapause along with the rest of the population. The larvae were then left until May 1998 when survivors were counted and left undisturbed to complete their development. The resulting data from these experiments were analysed using the G-test.

\section{RESULTS}

\section{Woodwalton Fen National Nature Reserve}

Of the 756 larvae put out into the field for the prediapause treatment, 125 were recovered (17\%). For the diapause treatment 702 larvae were put into the field and 56 were recovered $(8 \%)$ and for the post-diapause treatment, 50 larvae from 486 put into the field were recovered $(10 \%)$ (Table 1). Due to the mobility and general ecology of $L$. $d$. batavus larvae those not recovered can be assumed to be fatalities.

Pre-diapause larvae: larval survival between plants, inclusive of both habitats over three years, was significantly higher on $R$. crispus than on either of the other Rumex species (Table 2 and see Table 3 for summary of statistics). Comparison of larval survival between plant species in the grassland habitat, over the three years, 
TABLE 2. Summary of larval survival of Lycaena dispar batavus on three Rumex species on Woodwalton Fen 19951998

\begin{tabular}{|c|c|c|c|c|c|c|}
\hline & \multicolumn{2}{|c|}{ R. hydrolapathum } & \multicolumn{2}{|c|}{ R. obtusifolius } & \multicolumn{2}{|c|}{ R. crispus } \\
\hline & $\mathrm{S}$ & $\%$ & $\mathrm{~S}$ & $\%$ & $\mathrm{~S}$ & $\%$ \\
\hline Pre-diapause & 32 & 13 & 28 & 11 & 65 & 26 \\
\hline Diapause & 23 & 10 & 21 & 9 & 12 & 5 \\
\hline Post-diapause & 18 & 11 & 19 & 12 & 13 & 8 \\
\hline \multicolumn{7}{|l|}{ Pre-diapause } \\
\hline Grassland & 21 & 17 & 19 & 15 & 30 & 24 \\
\hline Fenland & 11 & 9 & 9 & 7 & 35 & 28 \\
\hline \multicolumn{7}{|l|}{ Diapause } \\
\hline Grassland & 9 & 8 & 10 & 9 & 4 & 3 \\
\hline Fenland & 14 & 12 & 11 & 9 & 8 & 7 \\
\hline \multicolumn{7}{|l|}{ Post-diapause } \\
\hline Grassland & 9 & 11 & 11 & 14 & 8 & 10 \\
\hline Fenland & 9 & 11 & 8 & 10 & 5 & 6 \\
\hline
\end{tabular}

showed no significant differences between the plant species. Survival over the same period in the fenland habitat was significantly higher for larvae on $R$. crispus than on $R$. obtusifolius and $R$. hydrolapathum. Comparison of survival between fenland and grassland habitats $(15 \%$ \& $19 \%$ respectively) showed no significant difference.

Diapausing larvae: comparison between the three Rumex species, over three years in both habitats, showed no significant difference in larval survival (Tables $2 \& 3$ ), and no significant difference in survival among Rumex plants in the grassland habitat or in the fenland habitat. Comparisons of survival between the fenland and grassland habitats again showed no significant differences. Although no direct statistical comparisons were done on data between years, the survival rate for over-wintering larvae in fenland during 96/97 reached $25 \%$ which is comparable to the survival rate on $R$. hydrolapathum in the Weerribben during the winter of 97/98 (Table 1).

Post-diapause larvae: comparison of survival of postdiapause larvae among the Rumex species, over all years in both habitats, showed no significant differences (Tables $2 \& 3$ ). There was no significant difference in larval survival between species in the grassland, or in the fenland habitat. Comparisons between the fenland and grassland sites were also not significant.

A total of 121 larvae were recovered out of 992 larvae that were put out in the grassland habitat over the four years. Of these, $8 \%$ were subsequently found to be parasitised. In the fenland habitat 110 larvae were recovered out of 992 and, of these, $5 \%$ were found to be parasitised. A G-test showed that there was no significant difference in rates of parasitism between the grassland and fenland sites $(G=0.7$, d.f. $=2, P>0.05)$. Differences among plant species were not assessed in this study.
TABLE 3. Summary of statistical analyses on field experiments with $L$. d. batavus on 3 different Rumex species on Woodwalton Fen 1995-1998. Three years data are combined. $\mathrm{n}=$ 1,944

\begin{tabular}{lrcc}
\hline Site & G Value & df & P Value \\
\hline Pre-diapause & & & \\
Between species & 22.65 & 2 & $<0.001$ \\
Grassland & 3.52 & 2 & $>0.05$ \\
Fenland & 25.22 & 2 & $<0.01$ \\
Between habitats & 2.15 & 1 & $>0.05$
\end{tabular}

Diapause

$\begin{array}{llll}\text { Between species } & 4.26 & 2 & >0.05 \\ \text { Grassland } & 3.18 & 2 & >0.05 \\ \text { Fenland } & 1.84 & 2 & >0.05 \\ \text { Between habitats } & 1.92 & 1 & >0.05\end{array}$

\section{Post-diapause}

( 2 years data only)

\begin{tabular}{llll} 
Between species & 1.44 & 2 & $>0.05$ \\
Grassland & 0.56 & 2 & $>0.05$ \\
Fenland & 1.36 & 2 & $>0.05$ \\
Between habitats & 0.8 & 1 & $>0.05$ \\
\hline
\end{tabular}

\section{The Weerribben National Park}

On examination in early May 1998, 25\% larval survival was recorded on $R$. hydrolapathum plants but no larvae were found on either R. obtusifolius or R. crispus. It is not known whether the mortality occurred in the pre-diapause or diapause stage or accumulated gradually over time. The $25 \%$ survival rate on $R$. hydrolapathum is substantially higher than the combined survival rates for larvae overwintering on Woodwalton Fen which averaged only $8 \%$. However, Table 1 shows that for 1996/97 survival on $R$. hydrolapathum, in the fenland habitat, did reach as high as $25 \%$.

\section{DISCUSSION}

Comparisons of mean overall survival rates in this study (pre-diapause $17 \%$, diapause $8 \%$ and post-diapause $10 \%$ ) with previous work by Webb \& Pullin (1996) (prediapause $11 \%$, diapause $17 \%$ and post-diapause $56 \%$ ) shows broadly similar survival rates for the pre-diapause and diapause stages, but reveals a substantial difference between post-diapause survival rates. These differences could be the result of differing abilities of alternative Rumex to support post-diapause larvae although we could find no evidence for this. The reason is more likely to be attributable to annual variation in levels of predation/parasitism and/or severe flooding which is a characteristic of Woodwalton Fen.

Over the three years, pre-diapause larvae on $R$. crispus had a higher mean survival rate than on either of the other two Rumex species (although it was only significantly higher in the fenland habitat). This may be a reflection of the quality of the former species as a food-plant. Survival 
during the first year was very much higher on $R$. crispus in both areas and may have been due to high autumn temperatures and a lower than average rainfall at Woodwalton Fen (A. Bowley, pers. com.). Of the three Rumex species, $R$. crispus is more tolerant of drier conditions (Grime et al., 1988) which may have rendered it a better quality food-plant able to support small larvae in drought conditions. There is evidence that higher quality foodplants enable larvae to grow faster and spend less time feeding, thus allowing them to spend more time hidden and so escape predation (Slansky, 1993).

As early instar larvae were able to survive on $R$. crispus and $R$. obtusifolius in the field, and in the laboratory (Martin \& Pullin, 2004), it is unlikely that varying levels of secondary plant compounds between the plant species are an important factor in host plant selection among Rumex species.

High mortality rates in diapausing larvae are not uncommon in L. d. batavus (Duffey, 1968; Webb \& Pullin, 1996). Survival of larvae was not significantly different between the three Rumex species in this study, either overall or within habitat type. Predation is not thought to be the main factor in mortality of overwintering larvae and prolonged submergence of larvae during flooding episodes may be a contributing factor. Webb \& Pullin (1998) found that diapausing larvae could survive for up to 30 days submerged with no apparent effect on survival rates, but longer periods reduced survival significantly. Further experiments by Nicholls \& Pullin (2003) revealed that late diapausing larvae responded differently to the effects of flooding than early diapausing larvae, generally experiencing higher mortality rates than those in the early stage.

Some larval mortality at the post-diapause stage can be attributed to natural enemies. It is thought that post diapause larvae suffer from vertebrate rather than invertebrate predation from birds and small mammals (Duffey, 1968; Webb \& Pullin, 1996). Birds have been observed in the past feeding on L. dispar pupae (Purefoy, 1931) and Dempster et al. (1976) observed that Reed Buntings (Emberiza schoeniclus L.) are the main predator of later instars of P.m. britannicus in its fenland environment.

Post-diapause larvae are also very susceptible to flooding, a problem experienced over many years at Woodwalton Fen and responsible for the abrupt end of several re-establishment programmes (Webb \& Pullin, 1997). However, depending on the extent of the flood, some, if not all larvae can survive. For example, in 1997, $4^{\text {th }}$ instar larvae experienced spring flooding of compartment 39, during an experiment, but most were able to move to the upper parts of the plants to escape the water.

The fact that a proportion of larvae were able to survive each stage of their life cycle on alternative Rumex species in the field at Woodwalton Fen indicates that R. obtusifolius and $R$. crispus are possible suitable alternative foodplants. The reason they are not used may therefore lie in some feature of habitat structure in which these species grow. This was not apparent from the Woodwalton experiments but captive bred individuals were used in this comparison and may not have fully reflected the dynamics of the wild population.

It was possible to complete only one overwintering experiment on the wild population in the Weerribben due to low population density of larvae in subsequent years. Survival of overwintering larvae on $R$. hydrolapathum compared with total mortality on $R$. obtusifolius or $R$. crispus contrasts with the Woodwalton results. As the larvae had begun to feed on these two species after the experiment started, it would seem to confirm that they are acceptable as food-plants in terms of palatability, even for the wild population and that some other feature of the habitat, may be responsible for the observed total mortality. One fundamental difference at the end of the experiment in May was that $R$. hydrolapathum had almost no surrounding vegetation with plants plainly visible and few other insects, herbivorous or predatory, on them. In contrast $R$. obtusifolius and R. crispus in the grassland habitat were almost obscured by dense vegetation and were harbouring potential predators e.g. spiders, and other competitive herbivores including snails, moth larvae and beetles, especially Gastrophysa viridula a common herbivore of Rumex species.

Competition may therefore be influencing host-plant and habitat selection by L. dispar batavus. The chrysomelid beetle G. viridula is found on R. obtusifolius and $R$. crispus in their natural habitat and, although both larvae and adults feed on plant material, the larvae are particularly voracious and can easily defoliate a plant (Smith \& Whittaker, 1980b) causing direct competition for resources with other herbivores and/or rendering plants unsuitable for oviposition or subsequent larval survival. $G$. viridula is not found on $R$. hydrolapathum although a relative Galerucella nymphaeae does utilise this plant and could influence ovipositional choice. Differences in predation, parasitism or competition, such as that caused by the presence or absence of $G$. viridula, may have influenced or shifted the balance of female ovipositional preference to a particular resource and/or habitat and constitutes an interesting avenue for further investigation.

ACKNOWLEDGEMENTS. The authors are grateful to English Nature for their support of this work under their Species Recovery Programme (ref 03/GNT/202). Thanks also to Alan Bowley and his staff at Woodwalton Fen NNR and to Staatsbosbeheer for their collaboration and support of the fieldwork. We would also like to thank Colin Nicholls, Bill Shotton and Alec Mason for their assistance with field work.

\section{REFERENCES}

AtsatT P.R. 1981: Lycaenid butterflies and ants: selection for enemy-free space. Am. Nat. 118: 638-654.

Bernays E. \& Graham M. 1988: On the evolution of host specificity in phytophagous arthropods. Ecology 69: 886-892.

Damman H. 1987: Leaf quality and enemy avoidance by the larvae of a pyralid moth. Ecology 68: 88-97.

Dempster J.P., King M.L. \& Lakhani K.H. 1976: The status of the Swallowtail butterfly in Britain. Ecol. Entomol. 1: 71-84. 
Denno R.F., Larsson S. \& Olmstead K.L. 1990: Role of enemy-free space and plant quality in host-plant selection by Willow Beetles. Ecology 71: 124-137.

DufFey E. 1968: Ecological studies on the Large Copper butterfly, Lycaena dispar batavus, at Woodwalton Fen National Nature Reserve, Huntingdonshire. J. Appl. Ecol. 5: 69-96.

Fowler J. \& Cohen L. 1990: Practical Statistics for Field Biology. John Wiley \& Sons, Chichester.

Grime J.P., Hodgson J.G. \& Hunt R. 1988: Comparative Plant Ecology - A Functional Approach to Common British Species. Unwin Hyman, London.

Martin L.A. \& Pullin A.S. 2004: Host-plant specialisation and habitat restriction in an endangered insect, Lycaena dispar batavus (Lepidoptera: Lycaenidae) I. Larval feeding and oviposition preferences. Eur. J. Entomol. 101: 51-56.

Nicholls C.N. \& Pullin A.S. 2003: The effects of flooding on survivorship in overwintering larvae of the large copper butterfly Lycaena dispar batavus (Lepidoptera: Lycaenidae), and its possible implications for restoration management. Eur. J. Entomol. 100: 65-72.

OostermeiJer J.G.B. 1996: Actieplan Grote Vuurvlinder: Maatregelen voor Behoud en Uitbreiding. Report N. VS 96.27. De Vlinderstichting, Wageningen.

Pullin A.S. 1997: Habitat requirements of Lycaena dispar batavus and implications for re-establishment in England. $J$. Insect Conserv. 1: 177-185.

Pullin A.S. Balint Z., Balletto E., Buszko J., Coutsis J.G., Goffart P., Kulfan M., Lhonore J.E., Settele J. \& van der MAdE J.G. 1998. The status, ecology and conservation of
Lycaena dispar (Lycaenidae: Lycaenini) in Europe. Nota Lepidopter. 21: 94-100.

Purefoy E.B. 1931: Chrysophanus dispar batavus Oberhur in Wicken Fen: the romance of a beautiful and very rare butterfly. Entomologist 64: 265-267.

RhoAdes D.F. \& CATES R.G. 1976: Towards a general theory of plant anti-herbivore chemistry. Recent Adv. Phytochem. 10: 168-213.

Slansky F. Jr. 1993: Nutritional Ecology: The fundamental quest for nutrients. In: Stamp N.E. \& Casey T.E. (eds): Ecological and Evolutionary Constraints on Foraging. Chapman \& Hall, New York, pp. 29-91.

Smith R.W. \& WhitTaker J.B. 1980a: The influence of habitat type on the population dynamics of Gastrophysa viridula Degeer (Coleoptera: Chrysomelidae). J. Anim. Ecol. 49: 225-236.

SMith R.W. \& WhittaKer J.B. 1980b: Factors affecting Gastrophysa viridula populations (Coleoptera: Chrysomelidae) in different habitats. J. Appl. Ecol. 49: 537-548.

ThALeR J.S. 1999: Jasmonate-inducible plant defenses cause increased parasitism of herbivores. Nature 399: 686-688.

WebB M.R. \& Pullin A.S. 1996: Larval survival in populations of the large copper butterfly Lycaena dispar batavus. Ecography 19: 279-286.

Webi M.R. \& Pullin A.S. 1997: The Orange Argus: a history of the large copper butterfly in Britain. Br. Wildlife 9: 29-37.

Webb M.R. \& Pullin A.S. 1998: Effects of submergence by winter floods on diapausing caterpillars of a wetland butterfly, Lycaena dispar batavus. Ecol. Entomol. 23: 96-99. 